\title{
Linear woody landscape elements may help to mitigate leaf surface loss caused by the cereal leaf beetle
}

\author{
Károly Lajos • Orsolya Császár • Miklós Sárospataki • Ferenc Samu • \\ Ferenc Tóth (i)
}

Received: 17 July 2019/Accepted: 17 August 2020/Published online: 27 August 2020

(C) The Author(s) 2020

\begin{abstract}
Context Woody semi-natural habitats serve as permanent habitats and hibernation sites for natural enemies and, through spillover processes, they play an important role in the biological control of insect pests. However, this service is also dependent on the amount and configuration of the dominating woody habitat types: linear landscape elements (hedgerows, shelterbelts), and more evenly extended plantations. Relating natural enemy action to the landscape context can help to identify the effect of woody habitats on biological control effectiveness.

Objectives In the Central European agricultural landscapes such as in the Hungarian lowlands, where our study took place, woody linear elements are
\end{abstract}

Electronic supplementary material The online version of this article (https://doi.org/10.1007/s10980-020-01097-3) contains supplementary material, which is available to authorized users.

K. Lajos · M. Sárospataki

Department of Zoology and Animal Ecology, Szent István University, Páter Károly utca 1, Gödöllő 2100, Hungary

O. Császár · F. Tóth ( $₫)$

Department of Integrated Plant Protection, Plant

Protection Institute, Szent István University, Páter Károly

utca 1, Gödöllő 2100, Hungary

e-mail: toth.ferenc.nvi@szie.hu

F. Samu

Centre for Agricultural Research, Plant Protection

Institute, Herman Ottó út 15, Budapest 1022, Hungary characterised by high, while woody areal elements, mostly plantations, by low biological and structural diversity. In this study, we aimed to determine which composition and configuration of woody linear and areal habitats in the landscape may enhance the effect of natural enemy action on plant damage caused by the cereal leaf beetle (CLB, Oulema melanopus).

Methods Herbivory suppression by natural enemies was assessed from the leaf damage difference between caged and open treatments. These exclusion experiments were carried out in 34 wheat fields on plants with controlled CLB infections. The results were related to landscape structure, quantified by different landscape metrics of both woody linear and areal habitats inside buffers between 150 and $500 \mathrm{~m}$ radii, surrounding the wheat fields.

Results The exclusion of natural enemies increased the leaf surface loss caused by CLBs in all fields. Shelterbelts and hedgerows in 150-200 m vicinity of the wheat fields had a strong suppressing effect on CLB damage, while the presence of plantations at $250 \mathrm{~m}$ and further rather impeded natural enemy action.

Conclusions Our results indicate that shelterbelts and hedgerows may provide a strong spillover of natural enemies, thus contribute to an enhanced biological control of CLBs. 
Keywords Oulema melanopus - Landscape metrics . Natural enemies · Biological control $\cdot$ Exclusion experiments

\section{Introduction}

The importance of semi-natural habitats (SNHs) for natural enemies of crop pests has already been demonstrated in a number of studies (Geiger et al. 2008; Woltz et al. 2012; Alignier et al. 2014; Sarthou et al. 2014). Besides herbaceous SNHs, like grasslands and pastures, woody SNHs are also an important part of the Central-European agricultural landscapes. Such habitat patches roughly fall into two categories. One is elongated, linear landscape elements, such as shelterbelts and hedgerows. These are rather common sights, since they were established as windbreaks along country roads and field boundaries. In Hungary, already in the 1950-1960s their secondary purpose was regarded as providing nesting sites for birds and shelter for natural enemy species, of which many use shelterbelts or hedgerows as foraging habitats, breeding and hibernation sites (Takács and Frank 2009). Commonly, they have a rich understory possessing high biological and structural diversity. Shelterbelts and hedgerows have been shown to enhance the abundance and diversity of natural enemies in the adjacent crop fields, thus supporting the biological control of different agricultural pests (see for instance: Holland and Luff 2000; Kujawa et al. 2006; Thomson and Hoffmann 2009, 2010, 2013; Morandin et al. 2011; Morandin et al. 2014). This has been demonstrated to be based on metapopulation processes which affect the distribution of natural enemies in seminatural and crop habitat patches at the landscape scale (Samu et al. 2018). An important mechanism that controls this process is the spillover of natural enemies across the non-crop-crop interface, which depends on the habitat identity of the patches, as well as on the structural features of the landscape (Tscharntke et al. 2007).

In contrast to linear elements, other woody habitat patches have a more extended area. The naturalness, plant diversity and structural heterogeneity of areal woody areas play an important role in maintaining a diverse natural enemy population and contribute to their spillover (Theron et al. 2020). In Hungary areal woody landscape elements with higher naturalness are mostly restricted to the highlands of the country (Bartha and Gálhidy 2007). In the lowlands of Hungary, which is the main agricultural area, apart from the few remnant patches of the forest-steppe vegetetation (Erdös et al. 2018), the woody areal patches are mostly plantations of poplar (Populus tremula), black lockust (Robinia pseudoacacia) and pines (Pinus silvestris, P. nigra) with strong canopy closure and predominantly low biological and structural diversity (Weih et al. 2003; Vítková et al. 2017). Moreover, these plantations mostly host forest specialist insects, which are strongly restricted to these habitats and tend to avoid entering more open habitats like cropland, as shown for example for spider and carabid assemblages (Sunderland and Samu 2000; Fischer et al. 2013).

Besides uncovering the habitat preferences of natural enemies, it is also very important to quantify their suppressive impact on agricultural pest activity and damage. This can be experimentally tackled by assessing plant damage when natural enemies can freely act on the pest organism(s) and compare this to situations where natural enemies are excluded by some experimental manipulation. This way, the pest species can cause plant damage unrestricted by their natural enemies (Holland et al. 2012). In cereal fields, however, previous studies have mainly focused their research on the exclusion of the natural enemies of aphids and their relationship with the landscape context, analysing either the relationship between landscape complexity and natural enemy abundance (Caballero-Lopez et al. 2012) or the effects of landscape features, including scale-dependencies, on the outcome of exclusion treatments (Woltz et al. 2012; Martin et al. 2015). The spillover of parasitoid and predatory natural enemies of aphids to crop fields was enhanced by landscape complexity (Thies et al. 2005), but the effect of this process diminished towards field interiors (Zhao et al. 2013).

Apart from aphids, another economically important insect pest of small grain cereals in the northern hemisphere, is the cereal leaf beetle (Oulema melanopus L., CLB; Chrysomelidae, Coleoptera). The CLB preferably feeds on cereals like winter wheat, oat, rye and barley (Wilson and Shade 1966). The CLB, originally native to Eurasia, has become lately an invasive pest of small grain crops over large parts of North America (Olfert et al. 2004; Philips et al. 2011). 
CLB adults overwinter in ruderal or wooded areas in the proximity of the previous seasons' cereal fields (Casagrande et al. 1977; Philips et al. 2012). They emerge in early spring (Helgesen and Haynes 1972; Gutierrez et al. 1974) and migrate into cereal fields, where females lay 50-300 eggs (Philips et al. 2011) on crop leaves (Helgesen and Haynes 1972). After hatching, the larvae feed on leaves for 10-14 days, during which they pass four instars (Guppy and Harcourt 1978). They skeletonise the leaves by eating the upper epidermis and parenchyma, sparing only the lower epidermis (Gallun et al. 1967), leading to yield losses of up to $40 \%$ (Buntin et al. 2004) and a decrease in grain quality (Philips et al. 2011). The biological control of CLBs is well studied, pointing out the important role of both hymenopteran parasitoids (Kher et al. 2011; Philips et al. 2011; Roberts 2016; Kheirodin et al. 2020a), as well as insect and spider predators (Jenser 2003; Kheirodin et al. 2019, 2020a, b). Exclusion trials have already been applied to CLBs, demonstrating that natural enemies increase CLB egg mortality (Meindl et al. 2001).

At our present state of knowledge, however, the landscape context of CLB suppression by natural enemies has seldomly been studied. Tschumi et al. (2015) examined the effect of flowering strips along wheat fields on CLB, on natural enemy abundance and on plant damage in Swiss landscapes with different degrees of complexity. Adjacent flowering strips had a beneficial effect, however this effect was in the given study independent of the landscape context. Another recent study found positive associations of CLB abundance with the land cover of woody SNHs at scales of 1-2 km and negative associations with pastures at $2 \mathrm{~km}$ (Kheirodin et al. 2020a, b). However, neither of these studies addressed the effect of landscape configuration on CLB herbivory suppression, nor they examined the effect of woody landscape elements in particular. Woody habitat patches are especially of interest, since the presence of these habitats, contingent on their shape and distribution, benefits the natural enemies, as well as the CLB itself, as they serve as alternative habitats or overwintering sites for both.

In the present study we aimed to establish the suppression level of natural enemies on CLB damage and its dependence on the extent and configuration of two different types of woody habitats in the landscape, differentiating linear woody elements like shelterbelts and hedgerows from spatially more extended woody areas like plantations. (1) We hypothesized that natural enemies will reduce CLB herbivory. To test this hypothesis, we have established exclusion trials, predicting that the exclusion of natural enemies should increase the leaf surface loss on wheat plants artificially infested with CLB. (2) Further, we hypothesized that natural enemy action is determined by spillover from neighbouring habitats. This hypothesis was tested by the transect arrangement of the exclusion trials perpendicular to field edge, where we predicted a diminishing suppression effect towards the middle of the field. (3a) Thirdly, we hypothesized that the spatial configuration and distribution of two different types of woody semi-natural habitats in the landscape will have an effect on the suppression of CLB herbivory, expecting that linear woody elements will have a different impact on the herbivory suppression of the CLB compared to spatially more extensive, plantation type woody areas. We also hypothesized that (3b) these landscape effects will be scale-dependent. To test these hypotheses the herbivory suppression effects from the exclusion trials were analysed for potential landscape effects distinguishing between linear and extensive wooded areas in the landscape sectors, considered at multiple spatial scales.

\section{Materials and methods}

Study area

The study area was located in the north-western part of the Great Hungarian Plain, 80-100 m above sea level, in Jászság region, Jász-Nagykun-Szolnok County, in an area of approximately $150 \mathrm{~km}^{2}$ around the settlements of Jászárokszállás, Jászdózsa and Jászágó (Fig. 1a, b). This region has a continental, moderately warm and dry climate with average temperatures between 9.5 and $10.5{ }^{\circ} \mathrm{C}$ and average precipitation of $520 \mathrm{~mm}$ per year, with a minimum during the summer months. The number of sunshine hours per year is around 2000. Nowadays $90 \%$ of the region is under human influence, predominantly agricultural land, and untouched natural areas are rare. The natural and seminatural habitats in this region are mainly grasslands and pastures with small patches of forest remnants (Quercus robur, Fraxinus excelsior, Ulmus sp.) and with linear riparian forested areas along springs and 
(A)

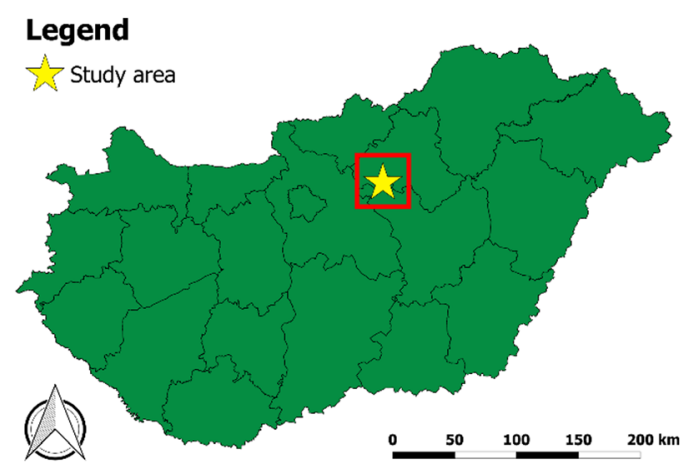

(C)

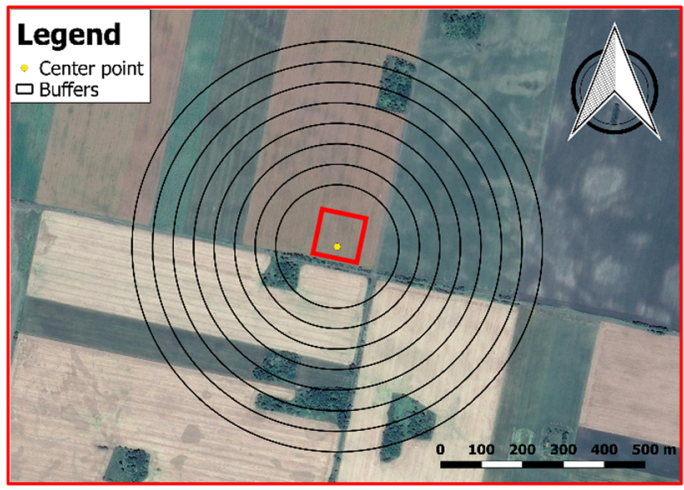

Fig. 1 a Location of the study area within Hungary (base map from GADM, the Database of Global Administrative Areas, www.gadm.org). b Positions of the 34 investigated wheat fields (the base map is an ESA Sentinel-2 Satellite Image from 2015-07-25). Fields, studied in 2014 are marked green, those in 2015 are orange. c Example for the circular buffers between radii of 150 and $500 \mathrm{~m}$ drawn around the centre point (yellow),

small rivers (Alnus glutinosa, Salix and Populus spp. often mixed with introduced species, such as Acer negundo, Celtis occidentalis, Ulmus pumila) (Buschmann 2011; Csiszár 2012). More extended forested areas in the agricultural landscape are dominated by plantations. The most common tree species in plantations in the Jászság region are poplar (Populus tremula) and black locust (Robinia pseudoacacia) (Buschmann 2011).

Experimental setup and management of the focal wheat fields

The field experiments took place in 2014 and 2015. In each year we selected 17 wheat fields as our focal fields (Fig. 1c). The management of all of the fields
(B)

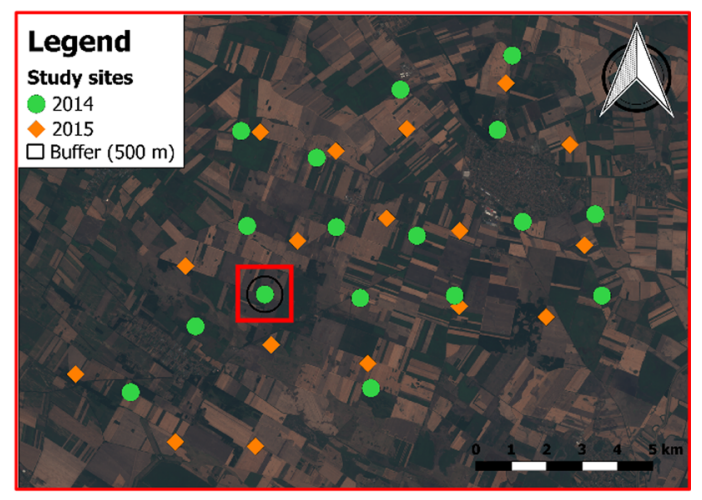

(D)

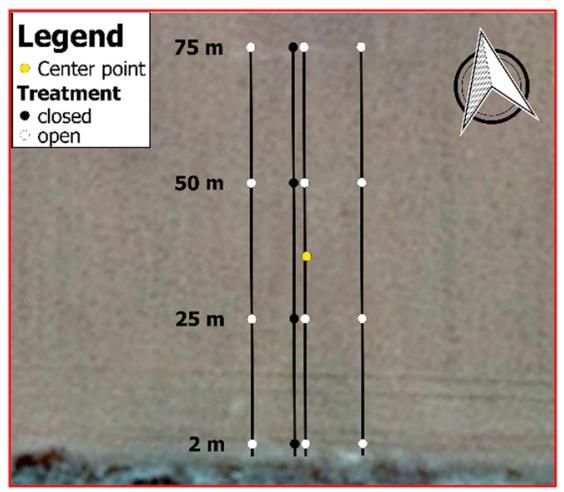

created to analyse possible scale effects (the base map is a Google Satellite Image from 2014). d Schematic drawing of the experimental setup within the landscape sector (the base map is a Google Satellite Image from 2014). The different treatments are indicated with the different colours of the dots. The red frames indicate the position of the consecutive figure $(\mathbf{b}-\mathbf{d})$

was conventional, using synthetic fertilizers. The field sizes ranged from approx. 6 to 100 hectares. The distance between fields studied in the same year was always larger than $1000 \mathrm{~m}$. The majority of the farmers also provided us information about the different wheat cultivars as well as the pesticide used. The most common pre-crop on the investigated fields was oilseed rape (Brassica napus L.), followed by sunflower, winter wheat and maize (Online Appendix Table 1). According to our field observations and the database MePAR, all forest patches located inside our landscape sectors were plantations.

In 2014, on each field, we designated three transects (wheat rows, perpendicular to field edge) for the experiments at $10 \mathrm{~m}$ distance from each other, plus a fourth one, $2 \mathrm{~m}$ left or right of the central row 
(Fig. 1d). In each of these four transects we selected individual plants at "transect distances" 2-25-50$75 \mathrm{~m}$ from the field edge to serve as host plants for caged populations of CLB adults. Plants were isolated under a mesh (Ikea 'Teresia', article number 602.603.30, weight $34 \mathrm{~g} / \mathrm{m}^{2}$, mesh size $0.25 \mathrm{~mm}$ ) supported by an iron frame (height $25 \mathrm{~cm}$, diameter $20 \mathrm{~cm}$ ). The bottom part of the mesh was isolated with washed, clay-free sand to prevent the escape of CLBs as well as the immigration of predators and parasitoids. The cages were set up between 14 and 17 April. Both male and female CLBs were collected with sweep nets, and five individuals, of which at least one was a male, were placed on the isolated individual plants. After 4-7 days the eggs laid were counted and the adults removed. Subsequently, the cages were placed back on plants in the additional central row (= "caged" treatment), while in case of the other rows we did not place back the cages, thus allowing the action of natural enemies (= "open" treatment). We set up a larger number of open wheat plants compared to the caged ones, because we expected higher fluctuations of the CLB herbivory in case of the open ones. The leaf damage caused by the CLB was assessed on 26-27 May. In 2015, in an otherwise identical experimental setup, only three rows were set up per field with the central row receiving the caged treatment and the lateral rows serving as the open treatments. Cage experiments were established on 23-24 April, and the leaf damage was inspected on 17-18 June.

Response variables

CLB herbivory was quantified as leaf surface loss per experimental wheat plant (LSL $L_{\text {PLANT }}$ ), which was visually determined as an average ratio of skeletonized leaf area in relation to the whole leaf area for 10 flagleaves of the plant. For answering hypotheses (1) and (2) we denoted the response variable as "LSL", which

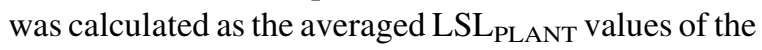
plants at a given transect distance in the given treatment in a field. Thus, in case of the open treatment at each transect distance the LSL value was calculated as the average of LSLPLANT values of $\mathrm{N}=03$ or $\mathrm{N}=02$ plants at the given transect distance observed in the two study years, respectively; whereas in case of the caged treatment for each transect distance LSL was equal to LSL $_{\text {PLANT }}$ of the singe plant that was observed.
To answer the landscape context related hypotheses (3a) and (3b) we calculated a single response variable that describes "herbivory suppression" in a given field, which was defined as the difference between the mean leaf surface loss ( LSL $_{\text {DIFF }}$ ) of the caged and open treatments. For this we averaged the LSL values across the transect distances separately for the two treatments to receive an $\mathrm{LSL}_{\mathrm{CAGED}}$ and an $\mathrm{LSL}_{\mathrm{OPEN}}$ value, from which LSL $_{\text {DIFF }}$ values were calculated for all 34 wheat fields according to the following equation:

$\mathrm{LSL}_{\mathrm{DIFF}}=\left(1-\frac{\mathrm{LSL}_{\mathrm{OPEN}}}{\mathrm{LSL}_{\mathrm{CAGED}}}\right)$

Mapping of landscape sectors around the fields

The surroundings of the 34 wheat fields were digitised in QGIS 2.18.9 (QGIS Development Team 2009), differentiating between hedgerows, shelterbelts and the woody floodplain vegetation of small creeks (woody linear, WL) and evenly extended forest patches or plantations (woody areal, WA). By our definition, WLs had a minimum width of $1.5 \mathrm{~m}$ and a length-width-ratio larger than 3:1. In case of WAs the length-width-ratio did not exceed 3:1. However, ringshaped woody landscape elements with a lengthwidth-ratio larger than $3: 1$ as well as irregularly shaped woody landscape elements with narrow parts were also considered as WAs. The minimum mapping unit for woody landscape elements was $100 \mathrm{~m}^{2}$ with more than $30 \%$ shrub or tree canopy cover. The georeferencing of the vector layers was done in the ETRS89/ETRS-LAEA (EPSG: 3035) coordinate reference system. For the digitisation we used Google Satellite Images from 2014 to 2016 as base maps. The identification of the woody landscape elements was always double-checked using the topographic map of Hungary of the open access database MePAR (FÖMI 2016) and satellite images from previous years. The landscape sectors were created in form of circular polygons of $500 \mathrm{~m}$ radii around the wheat fields, with the centres of the sampling transects serving as their centre points. These landscape sectors of $500 \mathrm{~m}$ radii were used as mask layers to clip layers from a larger digitised map containing the surroundings of the wheat fields. These vector layers were rasterized with an output raster size of $1 \times 1 \mathrm{~m}$. The resulting raster 
images were sieved for raster cells smaller than $4 \mathrm{~m}^{2}$ in order to remove lone pixels. Then, smaller, circular landscape sectors starting with radii of $150 \mathrm{~m}$ and consecutively increasing by $50 \mathrm{~m}$ up to $450 \mathrm{~m}$ were drawn around the centre of the 34 transects (Fig. 1c, cf. Thies et al. 2003). These polygons served then as mask layers to clip the basic raster images into images with consecutively smaller extent, resulting in 34 raster images for each of the 8 scales (from 150 to $500 \mathrm{~m})$.

\section{Calculation and selection of landscape metrics}

The raster images of the 34 landscape sectors described above were analysed with FRAGSTATS v4.2.1 in order to determine landscape metrics of the different woody landscape elements. All of the analyses carried out with FRAGSTATS v4.2.1 were performed at the class level with an 8-cell neighbourhood rule. We calculated 36 metrics from the 'Area and Edge', 'Shape' as well as 'Aggregation' metrics categories (McGarigal et al. 2012; McGarigal 2014). In case of 9 from these 36 metrics, besides the 'regular' mean value, we also determined the areaweighted mean. Additional statistical data like the median, range, standard deviation or the coefficient of variation of these nine metrics were left out from the calculations. Due to the large number of metrics, however, we decided to conduct a selection procedure on them: (1) We removed those metrics, where too many values were missing (NAs) or zeroes. (2) We also decided to preliminary drop the metrics 'Total Class Area', 'Total Edge' and 'Number of Patches', since they are completely redundant with 'Percentage of Landscape', 'Edge Density' and 'Patch Density'. (3) We calculated pair-wise Pearson's correlation coefficients between the remaining metrics from the largest scale of $500 \mathrm{~m}$ for each woody landscape element separately. For the graphical presentation of the results of the correlation analyses we used the R-package 'corrplot' (Weih et al. 2003), using the absolute values of the correlation coefficients (|r|) and applying a hierarchical clustering (see Online Appendix). Based on the clusters, we aimed to identify different groups of closely related metrics, from which we decided to select one metric to represent each group (Riitters et al. 1995), based on the variance and interpretability of these metrics. These were the metrics "Aggregation Index", "Edge Density",
"Largest Patch Index", "Patch Density" and the mean "Shape Index" for woody linear landscape elements (Online Appendix Table 3) and the metrics "Aggregation Index", "Related Circumscribing Circle", "Landscape Shape Index", "Percentage of Landscape" and the mean value of "Shape Index" for woody areal landscape elements (Online Appendix Table 4). The other metrics were discarded from further analyses. By the above procedure, separately for the linear and areal woody elements, we managed to identify a manageable initial set of quasi-orthogonal, well interpretable metrics that represented the main traits (related to area, edge, shape and aggregation) of these landscape elements, and could serve as a meaningful set of variables from which the effective ones could be selected in a further selection step during model creation (see next section).

Statistical analyses

To answer the questions in hypotheses (1) and (2) concerning the response variable LSL, we have built Generalised Linear Mixed Models (GLMM) with binomial distribution in R v3.6.3 (R Core Team 2018), using the R-package 'Ime4' (Bates et al. 2015). In this GLMM, we used the following predictor variables: The 'treatment' variable (levels: caged, open), 'transect distance' from field edge as a continuous variable, 'pesticide' treatment with four levels ('No Insecticide', 'Cyperkill Max', 'Decis' and 'Karate Zeon'), the area of the studied wheat field as 'field size' and the 'number of eggs' deposited by the introduced CLB adults at the beginning of procedure as continuous covariates. The 'field IDs' and the 'study year' were entered as random factors in this model. The binomial GLMM was then tested for over- or underdispersion with the 'dispersion_glmer' function from the 'blmeco' package (Korner-Nievergelt et al. 2015). In case we encountered an over- or underdispersion, we decided to switch to a quasibinomial GLMM using the 'glmmPQL' function from the 'blmeco' package. When evaluating the final model, in hypothesis (1) we were interested in the treatment effect, while in hypothesis (2) we needed to check the transect distance effect.

Before answering the questions formed in hypotheses (3a) and (3b), we tested the effects of relevant field-level predictor variables (as described above: 'pesticide', 'field size', mean 'number of eggs') on 
LSL $_{\text {DIFF }}$ and entered 'study year' as a random variable in a model. This was done in a linear mixed effect model testing all variables together, since we assumed that the distribution of LSL $_{\text {DIFF }}$ would be closer to a normal distribution. Departure from normality was checked by testing for skewness of $\mathrm{LSL}_{\mathrm{DIFF}}$ (package 'e1071' by Meyer et al. 2019). Since the values of LSL $_{\text {DIFF }}$ were negatively skewed, we reflected and square-root transformed them in order to fulfil the assumption of normality, which was checked with a Shapiro-Wilk test (Shapiro and Wilk 1965).

To describe how landscape context, stratified by scale levels, affects herbivory suppression (LSL DIFF ) to answer hypotheses ( $3 a$ ) and (3b), we first studied the spatial autocorrelation structure of this response by calculating Moran's I values using the R-package 'ape' (Paradis and Schliep 2019). The square-root transformed values of LSL $_{\text {DIFF }}$ were then included as dependent variables into linear models with the standardized metrics of woody SNHs as explanatory variables, for each scale separately. We entered the preselected set of explanatory variables into the initial models. To find the most influential variables from this set, we performed automated model selections based on a multimodel inference procedure from the 'MuMIn' package (Bartoń 2018). From this multimodel inference procedure, we kept those metrics, which occurred in the models with the lowest AICc values (delta $=0)$ and thus have the highest relative importance at multiple scales (Grueber et al. 2011; Symonds and Moussalli 2011). In case this procedure would lead to more than one metric, we would also test the models for multicollinearity between the metrics with Pearson's correlation analyses, carried out over all spatial scales, and variance inflation factors (VIFs) from the 'car' package (Fox and Weisberg 2019). The metrics remaining at the end of this selection procedure were then included in linear models. The fit of all models was a posteriori checked by inspecting residuals and QQ plots.

\section{Results}

\section{Exclusion effect on CLB herbivory}

Testing our first hypothesis, the final binomial GLMM showed that the exclusion of natural enemies had a strong effect on the level of herbivory (LSL), manifesting in highly significantly lower herbivory on the open plants (Table 1). The initial number of eggs (68.36 \pm 36.42 per isolator cage) deposited had a positive, significant effect on herbivory (Table 1). Whereas two of the insecticides applied on the fieldsDecis and Karate Zeon-showed weak, but significant effects, decreasing herbivory compared to those wheat fields, where no insecticides were used (Table 1). The variances for the two random effects were 0.5587 in case of the 'field IDs' and 0.0001 in case of the 'study year'. Importantly, in the final model transect distance had no significant effect on herbivory, which contradicted the second hypothesis proposing a diminishing spillover action of the natural enemies further inside the field (Table 1).

CLB herbivory suppression and woody landscape elements

The linear mixed effect model testing the influence of the independent field-level variables on LSL $_{\text {DIFF }}$ did not indicate any significant effect (Online Appendix Table 2), so none of these variables were included in the final models. The variance of the random effect 'study year' was 0 . The Moran's I calculated on the LSL $_{\text {DIFF }}$ data showed no spatial autocorrelation between the sites (observed $\mathrm{I}=-0.038$; expected $\mathrm{I}$ $=-0.030 ; \mathrm{p}$ value $=0.827$ ), so no correction of the model was necessary.

The results of the landscape analysis gave support to both our hypothesis $3 \mathrm{a}$ and $3 \mathrm{~b}$. Both types of woody landscape elements showed significant but contrasting effects on CLB herbivory suppression in the studied wheat fields and all these effects were scaledependent.

In case of WL patches, we found positive, significant effects of the metric 'Aggregation Index' on CLB herbivory suppression at multiple spatial scales (Table 2). These effects had their strongest impact at a scale of $200 \mathrm{~m}$. After this peak, there was a rather large drop at $250 \mathrm{~m}$, which was then followed by an increase in the effect strength at $300 \mathrm{~m}$, subsequently reaching a plateau of fluctuating values between scales of 350-500 m. We also found similar positive, significant effects in case of the metric 'Edge Density' (Table 2), but at a much narrower range of scales (150-200 m). The effects of 'Edge Density' were the strongest at the smallest scale of $150 \mathrm{~m}$, which was followed by a continuous drop of the effect strength to 
Table 1 Results of the binomial GLMM analysing the effects of exclusion treatments and other field scale variables on the LSL (Leaf Surface Loss) of the wheat plants caused by the CLB

\begin{tabular}{|c|c|c|c|c|}
\hline Variable & Estimate & Std. error & $\mathrm{z}$ value & $\operatorname{Pr}(>|z|)$ \\
\hline Intercept & 1.440 & 1.158 & 1.244 & 0.213 \\
\hline \multicolumn{5}{|c|}{ Exclusion treatment (reference level: caged) } \\
\hline Open & -4.814 & 0.724 & -6.650 & 0.000 \\
\hline Eggs & 0.019 & 0.007 & 2.925 & 0.003 \\
\hline Distance from field edge & -0.004 & 0.008 & -0.499 & 0.618 \\
\hline Area of wheat field & -0.012 & 0.013 & -0.936 & 0.349 \\
\hline \multicolumn{5}{|c|}{ Insecticide treatment (reference level: No Insecticide) } \\
\hline Cyperkill Max & 1.041 & 0.916 & 1.137 & 0.256 \\
\hline Decis & -1.717 & 0.934 & -1.838 & 0.066 \\
\hline Karate Zeon & -2.309 & 0.890 & -2.593 & 0.010 \\
\hline
\end{tabular}

The variables 'field IDs' and 'study year' were entered as random factors into the model. For further explanation, see text

Table 2 Results of the linear model analysing the effects of standardized influential landscape metrics of woody areal SNHs (WA, plantations) on herbivory suppression (LSL ${ }_{\text {DIFF }}$, analysed for multiple spatial scales (150-500 m)

\begin{tabular}{|c|c|c|c|c|c|}
\hline Metric & Scale $(\mathrm{m})$ & Estimate & Std. error & $\mathrm{t}$ value & $\operatorname{Pr}(>|\mathrm{t}|)$ \\
\hline \multirow[t]{8}{*}{ Percentage of landscape } & 150 & -0.002 & 0.001 & -1.544 & 0.167 \\
\hline & 200 & -0.003 & 0.001 & -3.032 & 0.013 \\
\hline & 250 & -0.003 & 0.001 & -4.132 & 0.001 \\
\hline & 300 & -0.003 & 0.001 & -3.064 & 0.008 \\
\hline & 350 & -0.003 & 0.001 & -2.966 & 0.007 \\
\hline & 400 & -0.003 & 0.001 & -2.901 & 0.008 \\
\hline & 450 & -0.003 & 0.001 & -2.889 & 0.008 \\
\hline & 500 & -0.002 & 0.001 & -2.231 & 0.035 \\
\hline
\end{tabular}

Influential landscape variables (here only Percentage of Landscape) were selected by automated model selections based on a multimodel inference procedure. For further explanation, see text

a minimum at $300 \mathrm{~m}$. Then, similarly to 'Aggregation Index', the effect strength increased again to a plateau of fluctuating values between 350 and $500 \mathrm{~m}$. The effect sizes $\left(\mathrm{R}^{2}\right)$ of linear models including both metrics were the highest at the smallest scales of 150-200 m, followed by a plateau of low values at 250-300 m and fluctuating values between 350 and $500 \mathrm{~m}$ (Fig. 2).

In contrast to WL patches, the metric 'Percentage of Landscape' of WA landscape elements had significant, negative effects on CLB herbivory suppression at all scales between 200 and $500 \mathrm{~m}$, with a peak value found at $250 \mathrm{~m}$ (Table 3). The effect sizes $\left(\mathrm{R}^{2}\right)$ of linear models including this metric also had their peak at $250 \mathrm{~m}$, followed by a rather continuous drop to a minimum at $500 \mathrm{~m}$ (Fig. 2).

\section{Discussion}

Our results from the exclusion experiments unequivocally supported our hypothesis that natural enemies will reduce the herbivory caused by the CLB. Prohibiting natural enemy access to the artificially infected wheat plants by isolator cages led to a significant increase in CLB herbivory. This coincides with the observation of Meindl et al. (2001), who observed a significantly lower mortality of CLB eggs, 
Table 3 Results of the linear model analysing the effects of influential standardized landscape metrics of woody linear SNHs (WL, shelterbelts and hedgerows) on herbivory suppression (LSL ${ }_{\text {DIFF), }}$ ) analysed for multiple spatial scales $(150-500 \mathrm{~m})$

\begin{tabular}{llllll}
\hline Metric & Scale $(\mathrm{m})$ & Estimate & Std. error & $\mathrm{t}$ value & $\operatorname{Pr}(>|\mathrm{t}|)$ \\
\hline Aggregation index & 150 & 0.015 & 0.005 & 3.216 & 0.005 \\
& 200 & 0.009 & 0.003 & 3.303 & 0.004 \\
& 250 & 0.004 & 0.004 & 0.993 & 0.332 \\
& 300 & 0.005 & 0.003 & 1.801 & 0.083 \\
& 350 & 0.011 & 0.004 & 2.819 & 0.008 \\
& 400 & 0.010 & 0.004 & 2.438 & 0.021 \\
Edge density & 0.013 & 0.004 & 2.992 & 0.005 \\
& 450 & 0.011 & 0.004 & 2.464 & 0.019 \\
& 500 & 0.001 & 0.000 & 3.804 & 0.001 \\
& 150 & 0.001 & 0.000 & 2.970 & 0.008 \\
& 200 & 0.000 & 0.000 & 1.336 & 0.195 \\
& 250 & 0.000 & 0.000 & 0.348 & 0.730 \\
& 300 & 0.000 & 0.000 & 1.284 & 0.209 \\
& 350 & 0.000 & 0.000 & 0.818 & 0.420 \\
& 400 & 0.000 & 0.000 & 1.009 & 0.321 \\
& 450 & 0.000 & 0.000 & 0.790 & 0.436 \\
\hline
\end{tabular}

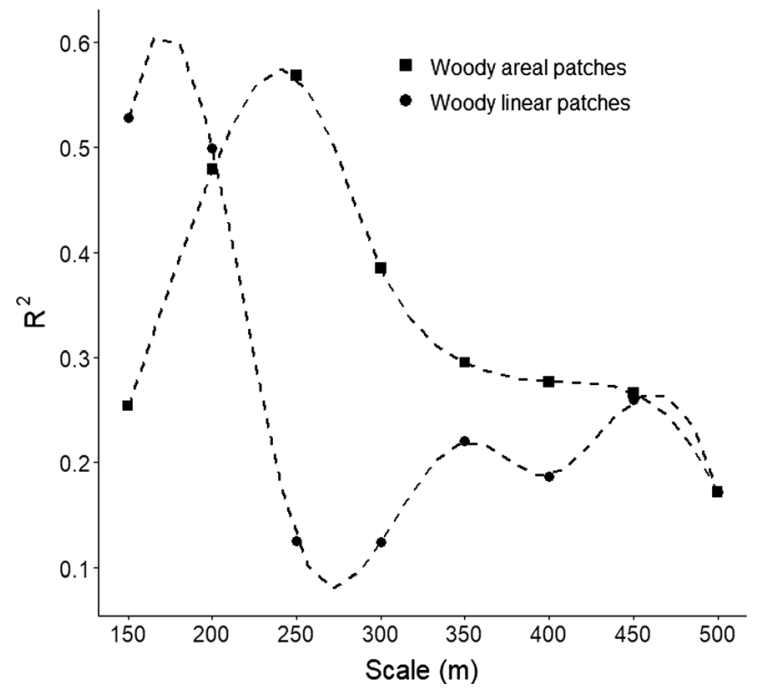

Fig. $2 \mathrm{R}^{2}$-values, taken from linear models testing the effects of different landscape metrics of woody linear and areal patches (WL and WA) on CLB herbivory suppression ( $\mathrm{LSL}_{\mathrm{DIFF}}$ ) for eight spatial scales between 150 and $500 \mathrm{~m}$ (see Tables 2 and 3)

when they were protected by isolator cages. However, other than that study we are not aware of any other research that would have assessed natural enemy impact on CLB applying field experimentation. At the same time, for other herbivorous groups there is an overwhelming evidence that natural enemy exclusion will increase herbivory by pests in various crops. In winter wheat, for instance, flying predators were responsible for $70 \%$ reduction in aphid population (Schmidt et al. 2003). In their extensive review Symondson et al. (2002) found that when the action of both generalist and specialist natural enemies were excluded, pest populations were reduced significantly in $89 \%$ of cases, and damage was reduced or yield increased significantly in five out of seven cases.

In our experiments, where exclusion was applied in a transect design, the suppressive action of natural enemies was demonstrated at every distance from the field edge, up to the maximal $75 \mathrm{~m}$ distance where isolator cages were set up. This result contradicts the observation of some previous studies (e.g. Zhao et al. 2013; Boetzl et al. 2018). However, other studies, like the one conducted by Bowie (1999), got similar results finding no diminishing tendency in the abundance of aphid parasitoids (Aphidius spp.) in wheat fields with increasing distance from field edge. Lack of diminishing herbivory suppression towards midfield may either indicate that natural enemy action is not externally influenced or may suggest that spillover from neighbouring habitats has a larger action radius than covered in the present study. We argue, that other results from the present study give support to this latter possibility. In itself, the positive influence of the wooded-non-wooded interface suggests that processes occurring on boundaries, such as a spillover process, play an important role. The peak of this 
enhancement for the metric 'Edge Density', which is a measure for the amount of boundaries of a landscape element, was between 150 and $200 \mathrm{~m}$ and thus larger than the distance we covered with the transect towards the middle of the field. Large spillover radius of natural enemies is important for their efficient plant damage mitigation because Oulema spp. densities have been shown to increase towards field interiors in a Belgian study (Van De Vijver et al. 2019). Our estimation of spillover scale is similar to the observations made by Martin et al. (2015), who reported a scale-dependency of landscape effects on the studied parasitoids of aphids, which was the strongest at a scale of $200 \mathrm{~m}$. The results of another study conducted by Evans et al. (2015) also coincide with our observations, who found that the parasitization rate of CLB larvae by Tetrastichus julis, a host-specific parasitoid wasp of the CLB, was the strongest at 50-100 m distance from field edge in wheat fields.

The results from the application of insecticides at some of the fields, which occurred as a 'natural experiment', may also support our argument about the importance of the spillover process. The application of insecticides had a suppressive effect on the absolute amount of damage caused by the CLB. However, natural enemy action seemed not to be influenced by these chemical treatments, as the differential herbivory between open and caged treatment was not affected by the insecticide application. Indirectly this result allows speculation, that even if short action insecticides also harmed natural enemies, they have been soon replenished, presumably through spillover processes. This dynamism of natural enemies taking refuge in semi-natural habitats during pesticide application and afterwards recolonising crop fields have been demonstrated in a number of studies (Duffield et al. 1996; Gontijo 2019).

We have uncovered that, as we predicted, woody elements in the landscape did influence herbivory suppression in the field. While many studies examined the relationship between landscape complexity and natural enemy abundance and diversity, there are much fewer studies that would directly focus on the relationship between landscape features and pest damage suppression (Chaplin-Kramer et al. 2011; Salek et al. 2018; Kheirodin et al. 2020a, b). Our analysis of woody landscape elements indicated that the extent and type of wooded habitat is important in this regard. Linear wooded habitats, which mostly included shelterbelts and hedgerows, had markedly increased herbivory suppression. This coincides with other previous observations, like the ones made by Dong et al. (2015), who found that a larger area of shelterbelts resulted in larger ladybeetle abundances through spillover. Linear seminatural landscape elements, as "green veins" in the agricultural landscape, have been shown to increase the diversity of many organisms, including natural enemies in a wide range of studies (Grashof-Bokdam and van Langevelde 2005). Dabrowska-Prot and Wasilowska (2012) demonstrated that ecotones along habitat boundaries have important function in creating higher diversity, as they comprise specific microhabitats and often have special abiotic characteristics. Shelterbelts significantly increased spider spillover to crop fields in another Polish study (Kajak 2007). The quality and composition of linear woody elements, such as hedgerows, is also an important determinant of natural enemy spillover. High diversity of non-tree woody plants was more valuable for linyphiid spiders, while the presence of trees within hedgerows supported lycosid spiders in an English study (Garratt et al. 2017).

Compared to the positive effects of linear woody elements, however, we found that extensive plantations in the landscape may impede natural enemy action. If the interior of extensive wooded areas has a limited overlap in species composition with agricultural fields, then only limited spillover can be expected. This has been found over a number of case studies in a review by Samu et al. (1999). Predation pressure experiments also indicated a lack of spillover of predators between forested habitats and corn fields (Ferrante et al. 2017). Areal woody elements in the present study were plantations, without exemption. These woody areas in the Hungarian agricultural landscape offer a rather impoverished, homogenised habitat (Bartha and Gálhidy 2007) that is critically different from crop fields. This leaves little space for processes such as landscape complementation or supplementation for potential natural enemy species (Fahrig et al. 2011) and cannot be expected to enhance diversity in the field (Martinez et al. 2015). In this regard areal wooded areas can be considered as a matrix habitat from the perspective of arable natural enemy community, and as such, poor matrix quality will rather have an isolation than an enhancement effect (Prevedello and Vieira 2010; Watling et al. 2011). Furthermore the unfavourable matrix habitat 
will impede the dispersion of non-forest species (Vasudev et al. 2015). While not included in our experimental approach, it has to be noted that forested areas may increase CLB density (Kheirodin et al. 2020a, b). Forests offset CLB biological control (Tscharntke et al. 2016) by providing overwintering habitats for adults beetles (Casagrande et al. 1977; Philips et al. 2012) and therefore enhance the spring migration of this pest to cereal fields. However, in other landscape settings, where areal woody areas are more natural and may offer resource supplementation (Erdős et al. 2018; Theron et al. 2020), the trade-off between these areas benefiting both natural enemies and pests might have a different outcome, and may actually tip toward a beneficial role that enhances pest suppression.

The supportive effect of linear wooded elements had a well-defined range of scale, which occurred to be the strongest when these habitats were closer to the focal field and clearly diminished at larger scales $(>200 \mathrm{~m})$. Contrastingly, the inhibiting effect of extensive wooded areas predominantly occurred at larger scales. Scale related effects are often taxonspecific, dependent on dispersal power, life history and several other factors (Thies et al. 2003; ChaplinKramer et al. 2011; Martinez et al. 2015) and the observed effects are likely to be the compound action from several natural enemy groups. The typical scale of the suspected spillover process and the type of habitat from which immigration is likely to occur, might give clues, as to which natural enemy groups might be responsible for the observed suppression of CLB herbivory. Hymenopteran parasitoids play a very important role in the biological control of CLBs (Philips et al. 2011; Kher et al. 2014; Roberts 2016) and their spillover can be expected to occur at smaller scales. Especially Necremnus leucarthros could be an important natural enemy of the CLB (Jeloková and Gallo 2008) and is one of the most common parasitoid species in Hungary (Szabolcs and Horváth 1991). Laboratory feeding preference trials (Meindl et al. 2001; Kheirodin et al. 2019) and molecular studies on field collected predators (Kheirodin et al. 2020a, b) demonstrated that carabid beetles, lady beetles (Coccinellidae), predatory bugs (Nabidae) and spiders are prominent natural enemies of CLB larvae, adults and also of eggs. Many of these predators have their habitats in forest patches, shelterbelts or hedgerows (Bianchi and Van der Werf 2003). Among the grounddwelling predators we also have to point out the potential role of different representatives of ants (Formicidae), which might be responsible for CLB herbivory suppression (Floate and Whitham 1994; Safarzoda et al. 2014).

Finally, we must also point out that in our study the CLB infestation of wheat plants was artificial and that we did not observe any strong infestation of the nonexperimental wheat plants in the investigated fields. This phenomenon, along with the basic findings of the exclusion trial, suggests that suppression of CLB damage, as an ecosystem service, works efficiently in the studied landscape. Based on our results we are convinced that we managed to find evidence for the suppressing effects of natural enemy species on the CLB, and could show that woody habitats, pertaining to shape, configuration and scale, importantly enhance this effect. Our study underlines the positive effects of green veining, the preservation and establishment of hedgerows and shelterbelts, which not only helps to enhance biodiversity in the agricultural landscape, but effectively contributes to pest damage suppression in crop fields.

Acknowledgements This research was funded by the European Union's Seventh Framework Programme for research, technological development and demonstrationQuESSA project (Grant Agreement No 311879; project administrator: John Holland; local administrator: József Kiss) - and was also supported by the Ministry for Innovation and Technology within the framework of the Higher Education Institutional Excellence Program (NKFIH-1159-6/2019) in the scope of plant breeding and plant protection research at the Szent István University. F. Samu was supported by NKFIH (OTKA) Grants K116062 K134811 during preparation of the manuscript. We would also like to thank our colleagues from the Plant Protection Institute of the Szent István University as well as the large number of MSc students for their help during this study.

Open Access This article is licensed under a Creative Commons Attribution 4.0 International License, which permits use, sharing, adaptation, distribution and reproduction in any medium or format, as long as you give appropriate credit to the original author(s) and the source, provide a link to the Creative Commons licence, and indicate if changes were made. The images or other third party material in this article are included in the article's Creative Commons licence, unless indicated otherwise in a credit line to the material. If material is not included in the article's Creative Commons licence and your intended use is not permitted by statutory regulation or exceeds the permitted use, you will need to obtain permission directly from the copyright holder. To view a copy of this licence, visit http://creativecommons.org/licenses/by/4.0/. 
Funding Open access funding provided by Szent István University.

\section{References}

Alignier A, Raymond L, Deconchat M, Menozzi P, Monteil C, Sarthou JP, Vialatte A, Ouin A (2014) The effect of seminatural habitats on aphids and their natural enemies across spatial and temporal scales. Biol Control 77:76-82

Bartha D, Gálhidy L (eds) (2007) A magyarországi erdők természetessége [Naturalness of Hungarian forests] (in Hungarian). WWF Magyarország, Budapest

Bartoń K (2018) MuMIn: multi-model inference. R package version 1.42.1. https://CRAN.R-project.org/package= MuMIn

Bates D, Mächler M, Bolker B, Walker S (2015) Fitting linear mixed-effects models using lme4. J Stat Softw 67(1)

Bianchi FJJA, Van der Werf W (2003) The effect of the area and configuration of hibernation sites on the control of aphids by Coccinella septempunctata (Coleoptera: Coccinellidae) in agricultural landscapes: a simulation study. Environ Entomol 32(6):1290-1304

Boetzl FA, Krimmer E, Krauss J, Steffan-Dewenter I, Lewis O (2018) Agri-environmental schemes promote grounddwelling predators in adjacent oilseed rape fields: Diversity, species traits and distance-decay functions. J Appl Ecol 56(1):10-20

Bowie MH (1999) Effects of distance from field edge on aphidophagous insects in a wheat crop and observations on trap design and placement. Int J Pest Manag 45(1):69-73

Buntin GD, Flanders KL, Slaughter RW, DeLamar ZD (2004) Damage loss assessment and control of the cereal leaf beetle (Coleoptera: Chrysomelidae) in winter wheat. J Econ Entomol 97(2):374-382

Buschmann F (2011) A Jászság természeti környezetének mai állapota. (The Current State of the Ecosystem within the Jászság Region). In: Bathó E and Papp I (eds) Szülőföldünk a Jászság. (Our Homeland). Jász Múzeumért Alapítvány, Jászberény, pp 9-15 (in Hungarian)

Caballero-Lopez B, Bommarco R, Blanco-Moreno JM, Sans FX, Pujade-Villar J, Rundlöf M, Smith HG (2012) Aphids and their natural enemies are differently affected by habitat features at local and landscape scales. Biol Control 63(2):222-229

Casagrande RA, Ruesink WG, Haynes DL (1977) The behavior and survival of adult cereal leaf beetles. Ann Entomol Soc Am 70(1):19-30

Chaplin-Kramer R, O’Rourke ME, Blitzer EJ, Kremen C (2011) A meta-analysis of crop pest and natural enemy response to landscape complexity. Ecol Lett 14(9):922-932

Csiszár Á (ed) (2012) Inváziós növényfajok Magyarországon (Invasive plant speceis in Hungary). Nyugat-magyarországi Egyetemi Kiadó, Sopron (in Hungarian)

Dabrowska-Prot E, Wasilowska A (2012) The role of ecotones in man-disturbed landscape: boundaries between mixed forest and adjacent man-made ecosystems in the Kampinos National Park, Poland. Pol J Ecol 60(4):677-698
Dong Z, Ouyang F, lv F, Ge F (2015) Shelterbelts in agricultural landscapes enhance ladybeetle abundance in spillover from cropland to adjacent habitats. Biocontrol 60:351-361

Duffield SJ, Jepson PC, Wratten SD, Sotherton NW (1996) Spatial changes in invertebrate predation rate in winter wheat following treatment with dimethoate. Entomol Exp Appl 78(1):9-17

Erdős L, Kröel-Dulay G, Bátori Z, Kovács B, Németh C, Kiss PJ, Tölgyesi C (2018) Habitat heterogeneity as a key to high conservation value in forest-grassland mosaics. Biol Conserv 226:72-80

Evans EW, Bolshakova VLJ, Carlile NR (2015) Parasitoid dispersal and colonization lag in disturbed habitats: biological control of cereal leaf beetle metapopulations. J Appl Entomol 139(7):529-538

Fahrig L, Baudry J, Brotons L, Burel FG, Crist TO, Fuller RJ, Sirami C, Siriwardena GM, Martin JL (2011) Functional landscape heterogeneity and animal biodiversity in agricultural landscapes. Ecol Lett 14(2):101-112

Ferrante M, González E, Lövei GL (2017) Predators do not spill over from forest fragments to maize fields in a landscape mosaic in central Argentina. Ecol Evol 7(19):7699-7707

Fischer C, Schlinkert H, Ludwig M, Holzschuh A, Gallé R, Tscharntke T, Batáry P (2013) The impact of hedge-forest connectivity and microhabitat conditions on spider and carabid beetle assemblages in agricultural landscapes. J Insect Conserv 17(5):1027-1038

Floate KD, Whitham TG (1994) Aphid-ant interaction reduces chrysomelid herbivory in a cottonwood hybrid zone. Oecologia 97(2):215-221

FÖMI (2016) MePAR, the Hungarian Agricultural Land Parcel Identification System. http://www.mepar.hu/. Accessed 22 Nov 2019

Fox J, Weisberg S (2019) An R companion to applied regression, 3rd edn. Sage, Thousand Oaks

Gallun RL, Everly RT, Yamazaki WT (1967) Yield and milling quality of monon wheat damaged by feeding of cereal leaf beetle. J Econ Entomol 60(2):356-359

Garratt M, Senapathi D, Coston D, Mortimer S, Potts S (2017) The benefits of hedgerows for pollinators and natural enemies depends on hedge quality and landscape context. Agric Ecosyst Environ 247:363-370

Geiger F, Wäckers FL, Bianchi FJJA (2008) Hibernation of predatory arthropods in semi-natural habitats. Biocontrol 54(4):529-535

Gontijo L (2019) Engineering natural enemy shelters to enhance conservation biological control in field crops. Biol Control 130:155-163

Grashof-Bokdam CJ, van Langevelde F (2005) Green veining: landscape determinants of biodiversity in European agricultural landscapes. Landsc Ecol 20(4):417-439

Grueber CE, Nakagawa S, Laws RJ, Jamieson IG (2011) Multimodel inference in ecology and evolution: challenges and solutions. J Evol Biol 24(4):699-711

Guppy JC, Harcourt DG (1978) Effects of temperature on development of the immature stages of the cereal leaf beetle, Oulema melanopus (Coleoptera: Chrysomelidae). Can Entomol 110(3):257-263

Gutierrez AP, Denton WH, Shade R, Maltby H, Burger T, Moorehead G (1974) The within-field dynamics of the 
cereal leaf beetle (Oulema melanopus (L.)) in wheat and oats. J Anim Ecol 43(3):627-640

Helgesen RG, Haynes DL (1972) Population dynamics of the cereal leaf beetle, Oulema melanopus (Coleoptera: Chrysomelidae): a model for age specific mortality. Can Entomol 104(6):797-814

Holland JM, Luff ML (2000) The effects of agricultural practices on Carabidae in temperate agroecosystems. Integr Pest Manag Rev 5(2):109-129

Holland JM, Oaten H, Moreby S, Birkett T, Simper J, Southway S, Smith BM (2012) Agri-environment scheme enhancing ecosystem services: a demonstration of improved biological control in cereal crops. Agric Ecosyst Environ 155:147-152

Jeloková M, Gallo J (2008) Parasitoids of cereal leaf beetle, Oulema gallaeciana (Heyden, 1879). Plant Prot Sci 44(3):108-113

Jenser G (ed) (2003) Integrált növényvédelem a kártevők ellen. (Integrated plant protection against pests). Mezőgazda Kiadó, Budapest (in Hungarian)

Kajak A (2007) Effects of forested strips on spider assemblages in adjacent cereal fields: dispersal activity of spiders. Pol J Ecol 55(4):691-704

Kheirodin A, Costamagna AC, Cárcamo HA (2019) Laboratory and field tests of predation on the cereal leaf beetle, Oulema melanopus (Coleoptera: Chrysomelidae). Biocontrol Sci Technol 29(5):451-465

Kheirodin A, Cárcamo HA, Costamagna AC (2020a) Contrasting effects of host crops and crop diversity on the abundance and parasitism of a specialist herbivore in agricultural landscapes. Landsc Ecol. https://doi.org/10. 1007/s10980-020-01000-0

Kheirodin A, Sharanowski BJ, Cárcamo HA, Costamagna AC (2020b) Consumption of cereal leaf beetle, Oulema melanopus, by generalist predators in wheat fields detected by molecular analysis. Entomol Exp Appl 168:59-69

Kher S, Carcamo LM, Dosdall H (2011) The cereal leaf beetle: biology, distribution and prospects for control. Prairie Soils Crops J 4:32-41

Kher SV, Dosdall LM, Carcamo HA (2014) Plant vigor metrics determine spatio-temporal distribution dynamics of Oulema melanopus (Coleoptera: Chrysomelidae) and its larval parasitoid, Tetrastichus julis (Hymenoptera: Eulophidae). Environ Entomol 43(5):1295-1308

Korner-Nievergelt F, Roth T, von Felten S, Guelat J, Almasi B, Korner-Nievergelt P (2015) Bayesian data analysis in ecology using linear models with R, BUGS and STAN. Academic Press, Cambridge

Kujawa K, Sobczyk D, Kajak A (2006) Dispersal of Harpalus rufipes (Degeer) (Carabidae) between shelterbelt and cereal field. Polish J Ecol 54(2):243-252

Martin EA, Reineking B, Seo B, Steffan-Dewenter I (2015) Pest control of aphids depends on landscape complexity and natural enemy interactions. PeerJ 3:e1095

Martinez E, Ros M, Bonilla MA, Dirzo R (2015) Habitat heterogeneity affects plant and arthropod species diversity and turnover in traditional cornfields. PLoS ONE 10(7):19

McGarigal K (2014) FRAGSTATS help. Documentation for FRAGSTATS, 4

McGarigal K, Cushman S, Ene E (2012) Spatial pattern analysis program for categorical and continuous maps. http://www. umass.edu/landeco/research/fragstats/fragstats.html University of Massachusetts, Amherst

Meindl P, Kromp B, Bartl B, Ioannidou E (2001) Arthropod natural enemies of the cereal leaf beetle (Oulema melanopus L.) in organic winter wheat fields in Vienna, Eastern Austria. IOBC/wprs Bull 24(6):79-86

Meyer D, Dimitriadou E, Hornik K, Weingessel A, Leisch F (2019) e1071: misc functions of the department of statistics, probability theory group (Formerly: E1071), TU Wien. R package version 1.7-1. https://CRAN.R-project. org/package $=\mathrm{e} 1071$

Morandin L, Long RF, Pease C, Kremen C (2011) Hedgerows enhance beneficial insects on farms in California's Central Valley. Calif Agric 65(4):197-201

Morandin LA, Long RF, Kremen C (2014) Hedgerows enhance beneficial insects on adjacent tomato fields in an intensive agricultural landscape. Agric Ecosyst Environ 189:164-170

Olfert O, Weiss RM, Woods S, Philip H, Dosdall L (2004) Potential distribution and relative abundance of an invasive cereal crop pest, Oulema melanopus (Coleoptera: Chrysomelidae), in Canada. Can Entomol 136(2):277-287

Paradis E, Schliep K (2019) Ape 5.0: an environment for modern phylogenetics and evolutionary analyses in R. Bioinformatics 35(3):526-528

Philips CR, Herbert DA, Kuhar TP, Reisig DD, Thomason WE, Malone S (2011) Fifty years of cereal leaf beetle in the U.S.: an update on its biology, management, and current research. J Int Pest Manag 2(2):1-5

Philips CR, Herbert DA, Kuhar TP, Reisig DD, Roberts EA (2012) Using degree-days to predict cereal leaf beetle (Coleoptera: Chrysomelidae) egg and larval population peaks. Environ Entomol 41(4):761-767

Prevedello JA, Vieira MV (2010) Does the type of matrix matter? A quantitative review of the evidence. Biodivers Conserv 19(5):1205-1223

QGIS Development Team (2009) QGIS Geographic Information System. Open Source Geospatial Foundation. http:// qgis.osgeo.org

RC Team (2018) R: a language and environment for statistical computing. R Foundation for Statistical Computing, Vienna

Riitters KH, O’Neill RV, Hunsaker CT, Wickham JD, Yankee DH, Timmins SP, Jones KB, Jackson BL (1995) A factor analysis of landscape pattern and structure metrics. Landsc Ecol 10(1):23-39

Roberts DE (2016) Classical biological control of the cereal leaf beetle, Oulema melanopus (Coleoptera: Chrysomelidae), in Washington State and rôle of field insectaries, a review. Biocontrol Sci Technol 26(7):877-893

Safarzoda S, Bahlai CA, Fox AF, Landis DA (2014) The role of natural enemy foraging guilds in controlling cereal aphids in Michigan wheat. PLoS ONE 9(12):e114230

Salek M, Hula V, Kipson M, Dankova R, Niedobova J, Gamero A (2018) Bringing diversity back to agriculture: smaller fields and non-crop elements enhance biodiversity in intensively managed arable farmlands. Ecol Indicators 90:65-73

Samu F, Sunderland KD, Szinetar C (1999) Scale-dependent dispersal and distribution patterns of spiders in agricultural systems: a review. J Arachnol 27(1):325-332 
Samu F, Horváth A, Neidert D, Botos E, Szita É (2018) Metacommunities of spiders in grassland habitat fragments of an agricultural landscape. Basic Appl Ecol 31:92-103

Sarthou J-P, Badoz A, Vaissiere B, Chevallier A, Rusch A (2014) Local more than landscape parameters structure natural enemy communities during their overwintering in semi-natural habitats. Agric Ecosyst Environ 194:17-28

Schmidt MH, Lauer A, Purtauf T, Thies C, Schaefer M, Tscharntke T (2003) Relative importance of predators and parasitoids for cereal aphid control. Proc R Soc B 270(1527):1905-1909

Shapiro SS, Wilk MB (1965) An Analysis of Variance Test for Normality (Complete Samples). Biometrika 52(3/4)

Sunderland KD, Samu F (2000) Effects of agricultural diversification on the abundance, distribution, and pest control potential of spiders: a review. Entomol Exp Appl 95:1-13

Symonds MRE, Moussalli A (2011) A brief guide to model selection, multimodel inference and model averaging in behavioural ecology using Akaike's information criterion. Behav Ecol Sociobiol 65(1):13-21

Symondson WOC, Sunderland KD, Greenstone MH (2002) Can generalist predators be effective biocontrol agents? Annu Rev Entomol 47:561-594

Szabolcs J, Horváth L (1991) Az Oulema fajok predátorai és parazita szervezetei Magyarországon. (Predators and parasites of Oulema species in Hungary). Növényvédelem 27(4):167-172 (in Hungarian)

Takács V, Frank N (2009) The traditions, resources and potential of forest growing and multipurpose shelterbelts in Hungary. Agroforestry in Europe. Springer, Dordrecht, pp 415-433

Theron KJ, Gaigher R, Pryke JS, Samways MJ (2020) High quality remnant patches in a complex agricultural landscape sustain high spider diversity. Biol Conserv 243:108480

Thies C, Steffan-Dewenter I, Tscharntke T (2003) Effects of landscape context on herbivory and parasitism at different spatial scales. Oikos 101(1):18-25

Thies C, Roschewitz I, Tscharntke T (2005) The landscape context of cereal aphid-parasitoid interactions. Proc R Soc B 272(1559):203-210

Thomson LJ, Hoffmann AA (2009) Vegetation increases the abundance of natural enemies in vineyards. Biol Control 49(3):259-269

Thomson LJ, Hoffmann AA (2010) Natural enemy responses and pest control: importance of local vegetation. Biol Control 52(2):160-166

Thomson LJ, Hoffmann AA (2013) Spatial scale of benefits from adjacent woody vegetation on natural enemies within vineyards. Biol Control 64(1):57-65
Tscharntke T, Bommarco R, Clough Y, Crist TO, Kleijn D, Rand TA, Tylianakis JM, Van Nouhuys S, Vidal S (2007) Conservation biological control and enemy diversity on a landscape scale. Biol Control 43(3):294-309

Tscharntke T, Karp D, Chaplin-Kramer R, Batáry P, DeClerck F, Gratton C, Hunt L, Ives A, Jonsson M, Larsen A, Martin EA (2016) When natural habitat fails to enhance biological pest control-five hypotheses. Biol Conserv 204:449-458

Tschumi M, Albrecht M, Entling MH, Jacot K (2015) High effectiveness of tailored flower strips in reducing pests and crop plant damage. Proc R Soc B 282:20151369

Van De Vijver E, Landschoot S, Van Roie M, Temmerman F, Dillen J, De Ceuleners K, Smagghe G, De Baets B, Haesaert G (2019) Inter- and intrafield distribution of cereal leaf beetle species (Coleoptera: Chrysomelidae) in Belgian winter wheat. Environ Entomol 48:276-283

Vasudev D, Fletcher RJ Jr, Goswami VR, Krishnadas M (2015) From dispersal constraints to landscape connectivity: lessons from species distribution modeling. Ecography 38(10):967-978

Vítková M, Müllerová J, Sádlo J, Pergl J, Pyšek P (2017) Black locust (Robinia pseudoacacia) beloved and despised: a story of an invasive tree in Central Europe. For Ecol Manage 384:287-302

Watling JI, Nowakowski AJ, Donnelly MA, Orrock JL (2011) Meta-analysis reveals the importance of matrix composition for animals in fragmented habitat. Global Ecol Biogeogr 20(2):209-217

Weih M, Karacic A, Munkert H, Verwijst T, Diekmann M (2003) Influence of young poplar stands on floristic diversity in agricultural landscapes (Sweden). Basic Appl Ecol 4(2):149-156

Wilson MC, Shade RE (1966) Survival and development of larvae of the cereal leaf beetle, Oulema melanopa (Coleoptera: Chrysomelidae), on various species of gramineae. Ann Entomol Soc Am 59(1):170-173

Woltz JM, Isaacs R, Landis DA (2012) Landscape structure and habitat management differentially influence insect natural enemies in an agricultural landscape. Agric Ecosyst Environ 152:40-49

Zhao Z-H, Hui C, He D-H, Ge F (2013) Effects of position within wheat field and adjacent habitats on the density and diversity of cereal aphids and their natural enemies. Biocontrol 58(6):765-776

Publisher's Note Springer Nature remains neutral with regard to jurisdictional claims in published maps and institutional affiliations. 